\title{
Karakteristik Anak Bungsu
}

\author{
Nilma Zola ${ }^{1 *}$, Asmidir Ilyas ${ }^{2} \&$ Yusri $^{3}$ \\ ${ }^{123}$ Universitas Negeri Padang \\ $\risingdotseq$ e-mail: zola@konselor.org
}

\begin{abstract}
Each child in the birth order has advantages and disadvantages, but the most often attracts attention in the family is the youngest child. The phenomenon found in the presence of younger children who lack the motivation of achievement, less independent, likes to seek the attention of others, and difficult to adapt in new environment and lack of willingness in taking responsibility. The type of this research is descriptive quantitative. Research subjects of all youngest children at Junior High School totaling 107 people. The results reveal that, (1) independence is generally in the category of less good; (2) adaptation in school is generally in very good category; (3) achievement motivation is generally in the less good category; and (4) responsibility in learning is generally in the good category.
\end{abstract}

Keyword: youngest child

Copyright (C) 2017 IICET (Indonesia) - All Rights Reserved

Indonesian Institute for Counseling, Education and Therapy (IICET)

\section{PENDAHULUAN}

Kedudukan atau posisi anak dalam keluarga bermacam-macam, ada anak sulung, anak kedua, anak ketiga dan seterusnya, ada juga anak tunggal serta anak bungsu. Masing-masing anak mendapatkan pola pengasuhan yang berbeda-beda dari orangtua yang akan membentuk kepribadian mereka. Menurut Agus Sujanto (2009:49), anak-anak menempati kedudukan yang khas pada umumnya lalu menujukkan tipe-tipe yang khas pula, sehingga memerlukan perlakuan, pelayanan atau pemomongan yang lain pula, agar tidak merugikan anak itu sendiri, merugikan anak yang lain ataupun merugikan keluarga.

Posisi urutan kelahiran (Birth Order) dalam keluarga memberikan pengaruh mendasar pada perkembangan anak, selanjutnya Forer (dalam Hurlock, 2013:62) menerangkan urutan kelahiran dalam keluarga yang pertama-tama dan tampak palig nyata akan mempengaruhi hubungan kita dengan orangtua. Tempat dalam keluarga menetapke peran spesifik yang dimainkan anak dalam keluarga. Hal ini mempengaruhi pembentukan sikap anak itu, baik terhadap dirinya sendiri maupun terhadap orang lain dan membantunya mengembangkan perilaku tertentu.

Sementara menurut Alwison (2009:79) dalam sebuah keluarga, setiap anak lahir dengan unsur genetik yang berbeda dan masuk dalam situasi sosial yang berbeda. Oleh karena itu, penting untuk melihat urutan kelahiran (anak pertama, kedua, dan seterusnya), dan anak-anak itu menginterpretasikan situasi dengan cara yang berbeda pula. Perbedaan kepribadian antar kakak-adik sebagian mungkin disebabkan oleh urutan kelahiran dalam keluarga (Woolfson, 2004:14).

Berdasarkan pendapat di atas dapat disimpulkan, urutan kelahiran anak dalam keluarga memberi pengaruh terhadap pembentukan kepribadian, sikap dan perilaku anak. Masing-masing anak dengan urutan kelahiran yang berbeda akan memiliki karakteristik, persepsi dan interprestasi terhadap situasi yang berbeda pula. Hal ini disebabkan karena unsur genetik dan situasi sosial yang berbeda terhadap tiap-tiap anak. 
Adler (dalam Hall \& Linzey, 2009:252) mengamati kepribadian anak sulung, anak tengah, dan anak bungsu dalam suatu keluarga akan berlainan. Ia mengaitkan perbedaan-perbedaan yang dimiliki setiap anak sebagai anggota suatu kelompok sosial. Masing-masing anak dalam urutan kelahiran mempunyai keunggulan dan kelemahan, namun yang paling sering menarik perhatian dalam keluarga adalah anak bungsu. Menurut Agus Sujanto (2009:54), dari orangtua, kadang-kadang nampak seakan-akan ada hak istimewa kepada anak bungsu, yaitu apabila orangtua itu mempunyai banyak anak, sehinga nampak status ekonomi sosialnya menurun. Dengan menurunnya status ekonomi sosial ini, si anak bungsu dirasakan sebagai anak yang hidup dalam keadaan yang tidak sama dengan waktu kakak-kakaknya masih kecil dahulu, dan orangtua mengkhayati hal semacam ini dengan mencurahkan perasaan dengan perbuatan-perbuatan yang menampakkan lebih menyayangi anaknya. Dari pihak saudara-saudaranya yang lebih besar, sianak bungsu inipun merasakan adanya perlakuan yang hampir sama dengan yang dilakukan oleh orangtuanya. Mereka, kakak-kakaknya itu selalu berusaha untuk menyayanginya, memanjakannya.

Singgih (2008:176), menyebutkan dalam masyarakat terdapat pendapat-pendapat umum bahwa anak bungsu adalah anak yang manja oleh karena menjadi pusat perhatian dari kakak-kakaknya, lebih-lebih lagi bila kakak-kakaknya berbeda usia cukup besar sehingga kedudukan anak bungsu ini benar-benar menjadi objek kesenangan anggota keluarga di rumah. Dengan mendapat perhatian yang terus menerus dari kakakkakaknya yang lebih dewasa dan dari orangtuanya, mengakibatkan sifat-sifat anak bungsu ini terlihat seperti kekanak-kanakan, cepat putus asa dan bila menginginkan sesuatu kemudian tidak tercapai, maka akan memberikan reaksi yang sifatnya emosional, misalnya cepat menangis, bertingkah laku secara berlebihan, dan lain-lain. Menurut Agus Sujanto (2009:54), karena terlalu disayang oleh orangtua dan kakak-kakaknya, terlalu banyak mendapatkan perhatian, perawatan, pertolongan, dan hiburan, maka si anak bungsu seakan-akan berada di dalam kehidupan yang serba kecukupan, serba menyenangkan, serba tersedia, dan serba mengenakkan. Semuanya ini memberi kesempatan kepada anak untuk berlaku manja. Perlakuan yang selalu diterimanya dari orang-orang di sekitar inilah yang membuat anak bungsu sering menjadi pemberontak, ceroboh dan tidak sabar.

Sama halnya dengan pendapat Gunawan Ardiyanto (2010:21) yang menyatakan sedikit sekali tuntutan pada anak bungsu karena orangtua sudah terlatih pada anak sulung. Mereka biasanya santai, akibatnya mereka menjadi rileks pada anak-anak yang lebih kecil. Dibandingkan dengan si sulung, si bungsu dalam keluarga cenderung kurang diawasi oleh orangtuanya. Baker (2004:21), juga menyebutkan anak bungsu dalam sebuah keluarga memiliki masalah yang sama dengan anak tunggal, selain juga tekanan orangtua mereka yang sudah lelah menjadi orangtua, dan kemarahan kakak-kakak mereka yang mengakibatkan tidak berlakunya semua tradisi di rumah, peraturan dan jam malam. Akibatnya anak ini tidak memiliki kemampuan untuk mengembangkan karakter yang kuat dalam bidang-bidang penting untuk kesuksesan dan keberadaannya di masa depan. Karena perlakuan yang diterima oleh anak bungsu inilah yang menyebabkan mereka seringkali bermasalah.

Alwison (2009:80) menyatakan "anak bungsu paling sering dimanja, sehingga beresiko tinggi menjadi anak yang bermasalah”. Hall \& Linzey (2009:253), anak bungsu adalah anak yang dimanjakan. Sama seperti anak sulung, kemungkinan besar ia menjadi anak yang mengandung masalah dan menjadi orang dewasa neurotik yang tidak mampu menyesuaikan diri. Hal yang sama di kemukakan oleh Agus Sujanto (2009:54), sikap manja akan selalu merugikan diri sendiri. Karena ia tidak akan mempunyai pengalaman untuk melakukan sesuatu. Padahal dapat melakukan sesuatu, berarti memiliki pengertian tentang sesuatu itu. Karena tidak dapat melakukan sesuatu, ia merasa malu dengan terhadap teman-temannya. Untuk menutupi rasa malu itu ia mengasingkan diri dari teman-temannya. Karena mengasingkan diri, ia kehilangan kesempatan untuk dapat berbuat yang lain, dan karena itu ia makin jauh mengasingkan dirinya, akhirnya ia tidak dapat berbuat apa-apa sehingga dapat menimbulkan stress (Taufik \& Ifdil, 2013).

Adapun karakteristik anak bungsu menurut Hurlock (2003:35) adalah sebagai berikut: 1) Cenderung keras (berjiwa bebas) dan agak penurut (lebih sopan); 2) Memiliki rasa aman yang tinggi karena tidak pernah disaingi oleh saudara-saudaranya (egois, manja); 3) Biasanya dilindungi oleh orangtuanya dari serangan fisik dan verbal kakak-kakaknya (tidak dewasa, manipulatif); 4) Cenderung tidak berprestasi tinggi karena kurangnya harapan dari orangtua (merasa dirinya inferior / rendah diri); 5) Mengalami hubungan sosial yang baik di luar rumah dan biasanya popular tetapi jarang menjadi pemimpin karena kurang kemauan untuk memikul tanggung jawab (tipe ekstrovert, suka bergaul, dan pendengar yang baik); 6) Cenderung bahagia karena memperoleh perhatian dan dimanjakan keluarga selama masa anak-anak (selalu menginginkan semua perhatian tertuju padanya). 
Hurlock (2013:64), juga mengemukakan, anak bungsu cenderung merasa aman, percaya diri, spontan, bersifat baik, murah hati, manja, tidak matang, ekstrovert, kemampuan berempati, merasa tidak mampu dan rendah diri, memusuhi saudaranya yang lebih tua, iri hati, tidak bertanggung jawab dan bahagia.

Dapat disimpulkan, idealnya anak bungsu cenderung bahagia karena memperoleh perhatian, perawatan dan pertolongan dari keluarga. Dan penyesuaian diri anak bungsu idealnya bagus. Anak bungsu pada umumnya periang, mereka pandai bergaul, pendengar yang baik, senang menjadi teman bicara, dan mudah akrab dengan orang yang baru dikenalnya, sehingga anak bungsu menjadi cukup populer di lingkungannya.

Kenyataan yang ditemukan di lapangan berdasarkan hasil observasi di SMPN 1 Lembang Jaya pada tanggal 15 Agustus 2016, diketahui beberapa anak bungsu mempunyai motivasi berprestasi yang rendah, hal itu ditunjukkan dari 110 anak bungsu yang tercatat di SMPN 1 Lembang Jaya hanya terdapat 12 orang yang memperoleh peringkat tiga besar. Selain motivasi berprestasi, kemauan memikul tanggung jawab pada beberapa anak bungsu di SMPN 1 Lembang Jaya juga kurang hal ini ditunjukkan dengan kemauan mereka menjadi pemimpin. Dari 15 kelas yang ada hanya 2 kelas yang ketua kelasnya adalah anak bungsu.

Kemudian hasil wawancara di SMPN 1 Lembang Jaya pada tanggal 15 Agustus 2016, dengan seorang guru BK dan seorang guru mata pelajaran diketahui beberapa anak bungsu cenderung lebih suka mencari perhatian di dalam kelas misalnya dengan mencemooh teman, dan ribut saat jam pelajaran berlangsung. Dan ada juga yang pendiam di kelas tidak terlalu bergaul dengan teman yang lain, fenomena yang satu ini sering di temui pada anak bungsu yang duduk di kelas VII (tujuh), hal itu menunjukkan mereka kurang dapat menyesuaikan diri dengan lingkungan baru.

Adapun tujuan yang hendak dicapai pada penelitian ini adalah mendeskripsikan; (1) Karakteristik anak bungsu berkaitan dengan kemandirian, (2) Karakteristik anak bungsu berkaitan dengan penyesuaian diri, (3) Karakteristik anak bungsu berkaitan dengan motivasi berprestasi, dan (4) Karakteristik anak bungsu berkaitan dengan tanggung jawab.

\section{METODOLOGI}

Penelitian ini bersifat deskriptif yang bertujuan untuk mendeskripsikan secara sitematis, faktual dan akurat mengenai fakta-fakta dari sifat-sifat populasi atau mencoba menggambarkan fenomena secara detail. Dengan demikian, penelitian ini mengungkapkan karakteristik anak bungsu di SMPN 1 Lembang Jaya, dengan jumlah subjek 107 orang. Instrumen penelitian yang digunakan adalah kuesioner model skala likert. Data yang diperoleh dianalisis dengan menggunakan teknik presentase.

\section{HASIL DAN PEMBAHASAN}

Bagian hasil adalah bagian utama artikel ilmiah. Bagian ini menyajikan hasil-hasil analisis data; yang dilaporkan adalah hasil bersih. Proses analisis data seperti perhitungan statistik, pengujian hipotesis tidak perlu disajikan. Jadi yang dilaporkan adalah hasil analisis dan hasil pengujian hipotesis.

Berdasarkan hasil penelitian yang dilakukan, karakteristi anak bungsu di SMPN 1 Lembang Jaya dapat dilihat pada tabel berikut ini.

Tabel Karakteristik anak bungsu secara keseluruhan

$$
\mathbf{n}=\mathbf{1 0 7}
$$

\begin{tabular}{|c|c|c|c|}
\hline Kategori & Interval Skor & $\mathbf{F}$ & $(\%)$ \\
\hline Sangat Baik & $\geq 169$ & 9 & 8,4 \\
\hline Baik & $\geq 130-<169$ & 94 & 88 \\
\hline Kurang Baik & $\geq 91-<130$ & 4 & 3,7 \\
\hline Tidak Baik & $<91$ & 0 & 0 \\
\hline \multicolumn{2}{|c|}{ Jumlah } & 107 & 100 \\
\hline
\end{tabular}


Berdasarkan tabel di atas dapat dilihat secara keseluruhan karekteristik anak bungsu, sebanyak 9 orang siswa $(8,4 \%)$ berada pada kategori sangat baik, 94 orang siswa $(88 \%)$ dikategorikan baik, dan 4 orang siswa $(3,7 \%)$ dikategorikan kurang baik. Temuan ini mengungkapkan bahwa keseluruhan karakteristik anak bungsu di SMP N 1 Lembang Jaya pada umumnya berada pada kategori baik.

\section{Kemandirian}

Menjadi mandiri tidak terwujud begitu saja namun ada tahapan yang di lalui seperti yang diungkapkan oleh Prayitno (2007:89), kondisi kemandirian tidak dapat dicapai seketika atau sekali jadi, melainkan melalui pentahapan. Setiap tahapan ini dilalui semenjak usia dini dan dipengaruhi oleh pola pengasuhan dalam keluarga. Artinya bagaimana pola pengasuhan dalam keluarga akan menentukan tingkat kemandirian anak.

Berkaitan dengan keterangan di atas, Agus Sujanto (2009:54) menge-mukakan, Karena terlalu disayang oleh orangtua dan kakak-kakaknya, terlalu banyak mendapat perhatian, perawatan, pertolongan, hiburan, maka si anak bungsu seakan-akan berada di dalam kehidupan yang serba berkecukupan, serba menyenangkan, serba tersedia dan serba mengenakkan. Semuanya ini memberikan kesempatan kepada anak untuk berlaku manja. Sikap manja, akan selalu merugikan diri sendiri. Karena ia tidak akan memiliki pengalaman untuk melakukan sesuatu.

Hal ini sesuai dengan pendapat Singgih (2008:176), dalam masyarakat terdapat pendapat-pendapat umum bahwa anak bungsu adalah anak yang manja oleh karena menjadi pusat perhatian dari kakak-kakaknya dan orangtua yang membuat anak bungsu cenderung bersikap kekanak-kanakkan. Hurlock (2003:35) menambahkan anak bungsu biasanya dilindungi oleh orangtua dari serangan fisik dan verbal kakak-kakaknya dan hal ini mendorong ketergantungan. Dari perlakukan yang didapatnya dari orangtua dan kakak-kakaknya membuat anak bungsu tidak dapat mengambil keputusan sendiri.

Berdasarkan hasil penelitian yang dilakukan, kemandirian anak bungsu di SMPN 1 Lembang Jaya pada umumnya dikategorikan kurang baik, hal itu ditunjukkan dari 107 orang siswa yang diteliti 69 orang diantaranya memiliki tingkat kemandirian yang berada pada kategori kurang baik, dan hanya 38 orang siswa yang tingkat kemandirian dikategorikan baik. Dapat diartikan lebih dari separuh jumlah subjek yang diteliti memiliki tingkat kemandirian yang kurang baik.

\section{Penyesuaian diri di sekolah}

Menurut Hadibroto (2003:19) si bontot, gelar yang terus melekat pada anak bungsu membuat anak bungsu menjadi perhatian orang, mereka sering menjadi maskot keluarga, tidak rumit dan cenderung ramah. Anak bungsu adalah anak yang menjadi pusat perhatian bagi teman-temannya. Menurut Hadibroto (2003:47) anak bungsu mempunyai segi positif yaitu: anak bungsu pada umumnya periang, mereka pandai bergaul, pendengar yang baik, senang menjadi teman bicara, dan mudah akrab dengan orang yang baru dikenalnya dan mudah menjadi populer. Hal yang sama juga dikemukan oleh Hurlock (2003:35) anak bungsu mengalami hubungan sosial yang baik diluar rumah dan biasanya populer. Dengan begitu mereka mudah diterima di lingkungannya termasuk di sekolah.

Berdasarkan hasil penelitian yang dilakukan, penyesuaian diri anak bungsu di SMPN 1 Lembang Jaya pada umumnya dikategorikan sangat baik, hal itu ditunjukkan dari 107 orang siswa yang diteliti 77 orang diantaranya memiliki penyesuaian diri yang sangat baik, dan 30 orang lainnya memiliki penyesuaian diri yang baik. Dapat diartikan lebih separuh dari jumlah subjek yang diteliti memiliki tingkat kemandirian yang sangat baik.

\section{Motivasi Berprestasi}

Gunawan Ardiyanto (2010:13) mengungkapkan anak bungsu mungkin merasa ia tidak mampu menyaingi prestasi kakak-kakaknya. Hurlock (2003:35) menambahkan anak bungsu cenderung tidak berprestasi tinggi karena kurangnya harapan dan tuntutan orangtua. Disebabkan perasaan seperti itulah anak bungsu memiliki semangat berkompetisi yang rendah.

Menurut hasil penelitian yang dilakukan dari motivasi berprestasi anak bungsu di SMPN 1 Lembang Jaya pada umumnya dikategorikan baik, hal itu ditunjukkan dari 107 orang siswa yang diteliti, 1 orang memiliki motivasi berprestasi yang sangat baik, 58 orang diantaranya memiliki motivasi berprestasi yang baik, dan 48 orang lainnya memiliki motivasi berprestasi yang kurang baik.. Dapat diartikan lebih separuh dari jumlah subjek yang diteliti memiliki motivasi berprestasi yang baik. 


\section{Tanggung Jawab dalam Belajar}

Umar Tirtarahardja \& La Sulo (2008:8) mengemukakan, kesediaan untuk menanggung segenap akibat dari perbuatan yang menuntut jawab, merupakan pertanda dari sifat orang yang bertanggung jawab. Wujud bertanggung jawab ada bermacam-macam. Ada tanggung jawab kepada diri sendiri, tanggung jawab kepada masyarakat, dan tanggung jawab kepada Tuhan.

Hurlock (2013:64), juga mengemukakan anak bungsu tidak bertanggung jawab. Mengalami hubungan sosial yang baik di luar rumah dan biasanya popular tetapi jarang menjadi pemimpin karena kurang kemauan untuk memikul tanggung jawab (Hurlock, 2003:35).

Menurut hasil penelitian yang dilakukan dari tanggung jawab dalam belajar anak bungsu di SMPN 1 Lembang Jaya pada umumnya dikategorikan baik, hal itu ditunjukkan dari 107 orang siswa yang diteliti, 43 orang memiliki tanggung jawab yang sangat baik, 56 orang diantaranya memiliki motivasi berprestasi yang baik, dan 8 orang lainnya memiliki motivasi berprestasi yang kurang baik. Dapat diartikan lebih separuh dari jumlah subjek yang diteliti memiliki tanggung jawab yang baik.

\section{SIMPULAN DAN SARAN}

Berdasarkan hasil penelitian dan pembahasan yang telah dipaparkan pada Bab IV mengenai karakteristik anak bungsu di SMPN 1 Lembang Jaya, dapat disimpulkan sebagai berikut: 1) Kemandirian anak bungsu pada umumnya berada pada kategori kurang baik, 2) Penyesuaian diri anak bungsu di sekolah pada umumnya berada pada kategori sangat baik, 3) Motivasi berprestasi anak bungsu pada umumnya berada pada kategori kurang baik, 4) Tanggung jawab anak bungsu dalam belajar pada umumnya berada pada kategori baik.

Berdasarkan kesimpulan dari hasil penelitan, maka akan disampaikan beberapa saran kepada pihakpihak terkait, yaitu: 1) Bagi konselor agar dapat memberikan bantuan kepada anak bungsu, dan 2) Bagi peneliti selanjutnya, diharapkan agar dapat meneliti permasalahan yang dialami anak bungsu dengan mendalami lagi penelitian dengan mengkaji Item-Item yang lain.

\section{DAFTAR RUJUKAN}

Aminuddin (Ed.). (1990). Pengembangan penelitian kualitatif dalam bidang bahasa dan sastra. Malang: HISKI Komisariat Malang dan YA3.

Agus Sujanto. (2009). Psikologi Kepribadian. Jakarta: Bumi Aksara.

Alwison. (2009). Psikologi Kepribadian. Malang: UMM Press.

Anas Sudijono. (2008). Pengantar Evaluasi Pendidikan. Jakarta: Rineka Cipta.

Atkinson, Rita L. \& Hilgard. (1983). Pengantar Psikologi. Batam: Interaksa Batam Centre.

Baker, Philip. (2004). Rahasia Super Achiever Menggali 15 Karakter Pribadi Super. Penerjemah: Daniel P. Purba \& Yati Sumiharti. Jakarta: Erlangga.

Chaplin, JP. (2008). Kamus Lengkap Psikologi. Alih Bahasa: Kartini Kartono. Jakarta: Rajawali Press.

Depdiknas. (2008). Kamus Besar Bahasa Indonesia. Jakarta: Gramedia Pustaka Utama.

Enung Fatimah. (2006). Psikologi Perkembangan (Perkembangan Peserta Didik). Bandung: Pustaka Setia.

Gunawan Ardiyanto. (2010). A to Z Cara Mendidik Anak. Jakarta: Elex Media Komputindo.

Hadibroto. (2003). Misteri Perilaku Anak Sulung, Tengah, Bungsu dan Tunggal. Jakarta: Gramedia Pustaka Utama.

Hall, S. Calvin \& Gardner Linzey. (2009). Teori-teori Psikodinamik (Klinis). Editor: A. Supratiknya. Yogyakarta: Kanisius.

Hallen. (2005). Bimbingan dan Konseling. Edisi Revisi. Jakarta: Quantum Teaching.

Hurlock, Elizabeth B. (2013). Perkembangan Anak Jilid 1 (Edisi Keenam). Jakarta: Erlangga.

Hurlock, Elizabeth B. (2003). Psikologi Perkembangan Suatu Pendekatan Sepanjang Rentang Kehidupan (Edisi Kelima). Jakarta: Erlangga.

Indriantoro \& Supomo. (1999). Metodologi Penelitian Bisnis untuk Akuntansi dan Manajemen. Yogyakarta: BPFE.

Irina Sokolova V. (2008). Kerpibadian Anak, Sehatkah Kepriadian Anak Anda?. Yogyakarta: Kata Hati 
Irzan Tahan. (2009). Hubungan Kemandirian Belajar dan Hasil Belajar pada Pendidikan Jarak Jauh. Jurnal Pendidikan Terbuka dan Jarak Jauh, Volume. 7, Nomor 2, September 2006, 91-101.

Kemendikbud. (2014). Modul : Diklat Implementasi Kurikulum 2013 untu Guru Bimbingan da Konseling (Konselor) SMP/MTs. Badan Pengembangan Sumber Daya Manusia Pendidikan dan Kebudayaan dan Penjaminan Mutu Pendidikan.

Notoatmodjo, S. (2003). Pendidikan dan Perilaku Kesehatan. Jakarta: Rineka Cipta.

Prayitno \& Erman Amti. (2004). Dasar-Dasar Bimbingan dan Konseling. Jakarta: Rineka Cipta. Prayitno. (2007). Peningkatan Potesi Mahasiswa. Padang: UNP Press.

Prayitno. (2012). Seri Panduan layanan dan kegiatan Pendukung Konseling. Padang: BK FIP UNP.

Riduan. (2005). Belajar Mudah Penelitian untuk Guru, Karyawan dan Peneliti Pemula. Bandung: Alfabeta.

Singgih D. Gunarsa. (2008). Psikologi Perkembangan Anak dan Remaja. Jakarta:Gunung Mulia.

Sofyan S. Willis. (2011). Remaja \& Masalahnya Mengupas Berbagai Bentuk Kenakalan Remaja, Narkoba, Free Sex, dan Pemecahannya. Bandung: Alfabeta

Sugiyono. (2011). Metode Penelitian Pendidikan (Pendekatan Kuantitatif, Kualitatif, dan R\&D). Jakarta: Alfabeta.

Sudarwan Danin. (2004). Motivasi Kepemimpinan dan Efektifitas Kelompok. Jakarta: Rineka Cipta.

Suharmisi Arikunto. (2006). Prosedur Penelitian Suatu Pendekatan Praktik. Jakarta: Rineka Cipta.

Taufik, T., \& Ifdil, I. (2013). Kondisi Stres Akademik Siswa SMA Negeri di Kota Padang. Jurnal Konseling dan Pendidikan, 1(2), 143-150.

Umar Tirtarahardja \& La Sulo. (2008). Pengantar Pendidikan. Jakarta: Rineka Cipta.

Woolfson, Richard C. (2004). Kenapa Anakku Begitu?. Penerjemah: Ariavita Purnamasari. Jakarta: Erlangga. 